\title{
Research on the Establishment and Improvement for China's Financial Supervision Coordination Legal System
}

\author{
Youfang Jin \\ Zhejiang University \\ Hangzhou, China
}

\begin{abstract}
China's financial supervision mode has no effective supervision for cross-sector innovative financial organizations or products. This paper wants to solve the regulatory gap, regulatory duplication and regulatory conflicts by establishing and improving the financial supervision coordination legal systems. The measures mentioned in this paper are clarifying the supervision coordination system with the People's Bank of China as the initiator and identifying rights and functions of the initiator; improving the financial supervision information sharing system, establishing the unified financial supervision information center and introducing operation rules for information sharing; establishing the financial supervision coordination system at the central and local level. During the construction of the financial supervision coordination system, the initiator system, the financial stability supervision committee, and the information collection and sharing system should be put in place. This paper can provide valuable references for China's legislation of financial supervision coordination or formulation of Methods for Financial Supervision Coordination.
\end{abstract}

Keywords-separate supervision; regulatory gap; supervision coordination; information sharing

\section{INTRODUCTION}

Separate operation and separate supervision are two striking characteristics of China's financial supervision mode. These two characteristics have been legalized by Article 43 of the Law of the People's Republic of China on Commercial Banks and Article 8 of the Insurance Law of the People's Republic of China. Meanwhile, these laws have authorized room for mixed operation of China's financial industry. To guarantee good order of separate operation, China has built a vertical separate supervision system integrating the People's Bank of China, China Banking Regulatory Commission, China Securities Regulatory Commission, and China Insurance Regulatory Commission (abbreviated as "One Bank, Three Commissions"). (1) Governed by the system of separate supervision, financial supervision institutions perform respective supervision duties. However, due to the blurry boundary of financial product and service supervision,

\footnotetext{
${ }^{11}$ According to the system, the People's Bank of China is responsible for national macro-prudential regulation, and has three major functions, namely "formulating and implementing currency policies, preventing and resolving financial risks, and maintaining financial stability under the leadership of the State Council” .
}

supervision is often overlapped or leaves some areas unsupervised.

Undoubtedly, emergence of mixed cooperation has intensified competition in the finance field. Especially along with popularization of Internet technologies, innovative financial products integrating functions of banking, securities and insurance have been popping up. Suppose that the separate supervision system of "One Bank, Three Commission” will not be changed in the short term, it is imperative to construct and improve the financial supervision coordination legal system for the sake of addressing problems, including regulatory gap and duplication, and maintaining financial stability and safety. This paper focuses on studying China's current financial supervision models and the financial supervision coordination system, and analyzing problems existing in China's current financial supervision coordination system. Meanwhile, a preliminary plan for construction and improvement of China's financial supervision coordination legal system is proposed based on China's national conditions.

\section{PROBLEMS EXISTING IN CHINA’S FINANCIAL SUPERVISION COORDINATION SYSTEM}

\section{A. Ambiguity of the legal position and responsibilities of the supervision coordination initiator}

The supervision coordination initiator is not clearly stipulated in the Law of the PRC on the People's Bank of China, the Law of the PRC on Securities or the Law of the PRC on Insurance, let alone functions, rights and obligations of the supervision coordination initiator. Currently, the financial supervision coordination departments set up by financial supervision departments are common to see. However, interministry co-presence meetings initiated by different financial supervision departments differ in terms of initiators, functions and responsibilities of the initiators, participants, scope of coordination supervision and disposal, etc. There are no basic institutional standards and procedural requirements to unify supervision coordination. As a result, multiple initiators of financial supervision coordination have appeared. Sometimes, the legal position, responsibilities, rights and obligations of financial institutions are even not well matched. Without a unified initiator in place, many financial supervision institutions are reluctant to take the initiative to coordinate their supervision activities. 
B. Obstacles of implementing the information sharing system among financial institutions

Information sharing is a basic prerequisite for various supervision institutions to cooperate each other on supervision coordination. Information symmetry is widely acknowledged as a carrier and prerequisite of efficient operation of the financial supervision coordination mechanism. Due to backward financial supervision infrastructure construction, China has not yet built a unified information sharing platform. The cost of information collection, recognition and processing is high.[1] Obstacles of information exchange have resulted in lack of coordination and communication channels among supervision institutions, and even directly influenced accuracy and timeliness of decision-making, thus making supervision less efficient.

In China's current law, there have not yet been any specific regulations on rights and obligations of neither information sharing, nor are there any systems restricting behaviors of information sharing. In China, supervision activities of the supervision institutions rely on acquisition of currency policies from the People's Bank of China. However, in reality, financial supervision institutions cannot immediately share macroscopic monetary policies issued by the People's Bank of China. Consequently, information resources are wasted. Besides, favorable information sharing operation system has not yet been put in place among financial institutions. This has largely hindered their information exchange. Major statistical data are distributed among major supervision departments. Information especially information about systematic risks are not collected and further compiled.

\section{Lack of institutional basis for coordination between central and local financial supervision institutions}

At present, China's local governments have played the role of supervising establishment and operation of a large number of small-micro financial institutions or private financial institutions. For example, the finance office is responsible for approving and supervising establishment and operation of folk capital management companies, folk credit service centers, and fund mutual help specialized cooperatives. However, as innovational financial products across three fields, namely banking, securities and insurance, keep on emerging, the institutional design of separate supervision and multi-party, multi-level supervision has been faced with severe challenges. There has not yet been any law basis for supervision departments to supervise a large number of folk financial entities. Thus, supervision departments shirk their responsibility on the excuse that they have no right to manage such affairs or that such affairs do not fall under the scope of their responsibility. Local government departments have been trying to gain supervision on local finance and Internet finance. Nevertheless, restricted by the deeply-rooted notion that traditional finance is the business of the central government and due to lack of legal basis for local government's financial supervision, the local financial supervision coordination activities have no laws to follow.

\section{ESTABLISHMENT AND IMPROVEMENT}

\section{SUGGESTIONS FOR CHINA'S FINANCIAL SUPERVISION}

\section{COORDINATION LEGAL SYSTEM}

In establishing the financial supervision coordination system, one should include major financial supervision coordination principles in different laws. The same supervision coordination issues should be logically consistently regulated in law. Legal responsibilities of the leader, scope of legal coordination, coordinated operation procedures, information sharing system, legal memorandum of understanding, and other major systems of financial coordination should be main considerations.

\section{A. Clarification of the supervision coordination system with the People's Bank of China as the initiator}

China follows the "One Bank, Three Commissions" separate financial supervision. Different supervision institutions are equal to each other in terms of their administrative rank. The People's Bank of China undertakes major responsibilities in national financial macro-regulation and maintenance of financial stability. As the ultimate institutional lender, the People's Bank of China is closely connected with the banking industry, securities industry, and insurance industry. In the real world, the People's Bank of China plays the role of the initiator [2] . In August 2013, the State Council approved the leading of the People's Bank of China as the initiator of financial institutions. However, the system is not a legal system. Besides, there have been many inter-ministry co-presence meetings which can serve as the initiator. Thus, the system lacks seriousness and restriction, and the legal functions and responsibilities of the leader are not clarified.

China's law has not yet set up a supervision institution entity called the general financial supervisor to conduct overall supervision and control of financial institutions [3]. Nor is there any initiator for supervision coordination. The current law mainly stipulates on the mutual coordination among equal entities. In foreign countries, such as in the US, the Federal Reserve Board (FRB) is authorized as the overall coordinator of financial supervision, which is responsible for supervising the financial holdings company. In the UK, the Prudential Regulatory Authority can give instructions to the Financial Conduct Authority or veto its instructions. Therefore, the role of the People's Bank of China as the initiator, including its functions, responsibilities, rights and obligations, should be clarified in the amendment of the Law of the PRC on the People's Bank of China or financial supervision coordination laws or administrative regulations should be specially formulated.

\section{B. Improvement of the information collection and sharing system among supervision institutions}

Establishment and improvement of the information collection and sharing system should take the following aspects into consideration:

First, reasonably distribute tasks of information collection. The People's Bank of China and other various supervision 
institutions should have relevant departments and personnel responsible for information collection, analysis and exchange not only in their own department information management system, but also across departments. Under the overall arrangement of the financial supervision coordination committee, various supervision institutions should sign an agreement on data and information sharing. Various supervision institutions should reach an agreement on which institution is responsible for collecting which information and on how to share information across departments. In this way, supervision information can be efficiently transferred between the People's Bank of China and supervision departments, and facilitate institutions' efficient performance of respective responsibilities[4] .

Second, set up the unified financial coordination information center dominated by the People's Bank of China. The People's Bank of China has different versions of financial information systems covering different services and functions. The People's Bank of China should announce content, time, frequency and channels of financial statistics in accordance with the principle of information transparency and sharing. Meanwhile, the People's Bank of China has the right to collect information from other financial institutions. The law should endow the People's Bank of China with the right to require other financial supervision departments and relevant government departments to cooperate with it in investigation or acquisition of information. On the other hand, implementation of the information sharing system should be strengthened to gather internal statistical institutions and personnel, technology department and personnel from the China Banking Regulatory Commission, China Securities Regulatory Commission and China Insurance Regulatory Commission as well as financial institutions and personnel to set up the China Financial Supervision Information Center. The Center will be responsible for overall planning, system construction, information connection, data processing and authentication.

Third, pin down the information sharing system among supervision institutions. For example, it should be pinpointed that, under which conditions, supervisors should be allowed to search information on the unified information platform, formulate unified standards and procedures for information sharing, adopt unified formats and requirements for information sharing, etc. The UK has done a good job in this field. The British government, after setting up the Financial Services Authority (FSA), issued the Memorandum of Understanding before long. The Memorandum of Understanding provides a labor distribution coordination framework for different financial supervision departments, and stipulates clearly on information collection, exchange and sharing.

\section{Establishment of a financial supervision coordination system at the central and local level}

The Decision of the CPC Central Committee on Several Issues about Comprehensively Deepening Reform points out that the supervision coordination mechanism should be improved, with financial supervision responsibilities and risk disposition responsibilities distinguished between the central government and the local government. For a long time, China has paid too much attention to issues of formal finance, namely banking, securities and insurance. The "One Bank, Three Commissions" supervision system is just applicable to the central level. At the local level, subsidiary departments of the “One Bank, Three Commissions" are set up. In the past, there had not yet been too many Chinese financial institutions. Most of them were licensed formal financial institutions. Currently, the number of folk financial institutions, shadow banks and Internet financial institutions has been multiplying. The smallscale operation represented by local small-scale deposit financial institutions has delegated their operation areas to counties, villages and towns based on their positioning to serve "agriculture, rural areas and farmers". It is no easy task for the “One Bank, Three Commissions" to supervise local smallmicro financial institutions, small lending companies, guarantee companies, capital management companies and Internet finance companies. On the contrary, the local governments have an edge in supervising them.

Most scholars have agreed on identifying the financial supervision right of local governments based on the principle of "administrative region and unification between rights and responsibilities”. The objects of local financial supervision are mostly acknowledged as the non-systematically significant financial institutions ${ }^{(2)}$. The small-scale deposit financial institutions, such as rural credit cooperatives and village banks, are large in number, and possess striking regional characteristics. The local government can give full play to their regional advantages in fully supervising these institutions. Therefore, these institutions can be transferred to local financial supervision. To facilitate local financial supervision, the local financial supervision bureaus of the provincial and municipal level should be set up, making them subject to the provincial and municipal government, respectively. The local financial supervision bureaus can also designate subsidiary institutions in counties. As the department responsible for local macroscopic management, the finance office should be devoted to planning, service, coordination, and performance of other functions excluding the financial supervision responsibilities. It should also take the lead in building the joint meeting system between the financial supervision bureau and the subsidiary institutions of the central government and "One Bank, Two Commissions”.

Now, China has been attaching increasing importance to the role of local financial supervision. Take Zhejiang Province for example. On November 22, the Zhejiang Provincial People's Congress passed the Regulations on Managing Private Financing in Wenzhou.[5] It is known as the first set of regulations targeted at private financing in China, which endows the Wenzhou municipal government with the right of supervising the private financing. The administrative right of the local government enables the local government to take the

\footnotetext{
${ }^{2}$ Refer to new-type financial institutions and business types outside the scope of administration by subsidiaries of the "One Bank, Three Commissions”, such as folk capital management companies, petty loan companies, financing guarantee companies, guarantee companies, financial information service companies, rural fund mutual help cooperatives, finance leasing companies, commercial insurance financial management companies, pawnbrokers, equity trading centers, private financing organizations, etc.
} 
lead to build the supervision coordination mechanism to alleviate the tension between local and central supervision institutions, and horizontally coordinate the interest relationship and conflicts of interest among different government departments. More importantly, it can quickly integrate various departments to effectively maintain regional financial stability when any financial emergencies occur. The multi-department administrative forces formed by the public securities, courts, industrial and administrative institutions, fiscal departments, audit and tax departments can provide vigorous support for financial supervision departments. Gradually, a comprehensive regional supervision coordination system will be shaped. Led by the financial office affiliated to the local government, the local financial institution coordination committee can be set up. On the basis, the representative elected by the supervision coordination committee of the central level and the local level should carry out financial supervision coordination on behalf of the central government and the local government, respectively. The Memorandum of Understanding on Central and Local Financial Supervision Coordination can be signed to dynamically adjust supervision coordination issues.

\section{CONCLUSIONS}

China's financial sector is booming. The system of separate operation and supervision might hinder mixed operation and Internet finance cross-sector operation of China's financial sector. This necessitates formulation of the financial supervision coordination system. In response to the development trend, the Chinese government should strengthen legislation o financial supervision coordination and establish the financial supervision coordination legal system to increase consistency of legal regulations on supervision coordination; clarify the legal position of the People's Bank of China to be the initiator of financial supervision, endow it with rights and functions as the financial "chief supervisor"; pinpoint the information collection and sharing system for financial supervision; distinguish the central financial supervision coordination system from the local one, etc.

\section{REFERENCES}

[1] Q. Zhang \& Zh. Sh. Wang, "Reflection on the institutional arrangement of coordinated cooperation of China's financial sector supervision," Finance \& Insurance, vol.4, 2005, pp.22. (In Chinese)

[2] H. W. Wen, "Research on coordination and cooperation of financial supervision under the current legal framework,” Journal of Guangdong University of Finance, vol.4, 2011, pp.124. (In Chinese)

[3] F. Liao, "Competition, conflict and coordination: Choice of regulatory model for cross-sector financial operation,” Journal of Peking University (Philosophy and Social Sciences), vol.3, 2008, pp.109. (In Chinese)

[4] Sh. H. Huang, "Imperativeness of building an effective coordination mechanism for the financial separate coordination,” Beijing Finance, vol.4, 2006, pp.17-20. (In Chinese)

[5] Y.X. Li, F.Chen \& Y.F. Jin, "A study on the regulation of the Internet Finane," Journal of Zhejiang University (Humanities and Social Sciences), vol. 4, 2014, pp. 87-97. (In Chinese) 